\title{
EFFICIENCY OF TRICHODERMA VIRIDE AND BACILLUS SUBTILIS AS BIOCONTROL AGENTS AGAINST ROOT ROT CAUSED BY FUSARIUM SOLANI IN TOMATO
}

\author{
KHALIL, M.E. \\ Integrated Pest Management Research Department. Plant Pathology Research. \\ Institute, Agricultural Research Center, Ministry of Agriculture, Giza, Egypt.
}

(Manuscript received 13 March 2019)

\begin{abstract}
$\mathrm{T}$ Tomato (cv.Peto-86) is one of the important crops all over the world. In Egypt and many other countries it is often attacked by several pathogens causing root rot. Trichoderma and Bacillus species are widely the most feasible biocontrol microorganisms that suppress several pathogens. The efficiency of both antagonistic organisms was evaluated in vitro. as well as in vivo against root rot of tomato. The inoculation with $T$. viride and or $B$. subtilis of tomato plant suppressed $F$. salani as indexed by survival rate. Field experiments, ware carried out at Senowras Fayoum governorate during 2017 and 2018 seasons,. The obtained results showed that, the tested fungicide Topsin-M70 and the two biocontrol agents significantly reduced the incidence of root rot of tomato. The fungicide was the most efficient treatment in this regard compared with the two tested bioagents. Two bioagents treatments favored greater proliferation of rhizophere microflora and dehydrogenase activity in the rhizosphere. It is recommended to use these strains as a common biocontrol application in agriculture.

Key words: Biological control, Fusarium solani Trichoderma viride, Bacillus subtilis and Tomato.
\end{abstract}

\section{INTRODUCTION}

Tomato (Lycopersicon esculentum Mill) is considered one of the most economic vegetable crops in Egypt either for exportation or local consumption. It is considered as one of the highest nutritional value. It contains antioxidants like vitamin $C$ as well as Lycopene which is used in cancer treatment (Giovannucci, 1999) and other many chemical compounds and elements which are not found in other Solanaceous crops. Tomato is subjected to the attack of numerous bacterial, fungal and viral diseases. However, diseases caused by fungi are more prevalent and distructive especially soil borne diseases such as root rots and wilt which cause considerable reduction to tomato production. Fusarium solani causes a serious damage on tomato plants either in nurseries or in open field (Abdel-Kader, et al., 2012, and Muhanna, et al. 2016). The natural control of several phytopathogens is based on the presence of antagonistic microorganisms such as those belonging to genera Trichoderma, Pseudomonas and Bacillus (Weller et al., 2002 Morsy, et al. 2009 Abdel-Kader, et.al, 2012, and Muhanna, et al. 2016).Trichoderma spp. are essential control phytopathogens affecting different crops (Soytong et.al, 2005 and Abdel-Kader, et.al, 2012,). Also, tomato plants inoculated with B.subtilis and / or T.harzianum showed 
low disease incidene and gave a higher yield of tomato (Maude,2006 , Zaghloul et al., 2007 and Muhanna et al. 2016).

The main goal of this study was to estimate the efficiency of T.viride and $B$. subtilis as bio-control agents against $F$. solani the causal pathogen of root rot disease in tomato.

\section{MATERIALS AND METHODS}

\section{Source of the tested fungi:}

Pure cultures representing an isolate of Fusarium solani pathogenic to tomato as well as the bio agents T.viride and B.subtilis were kindly obtained from the Vegetable Dis. Res. Dept., Plant Pathol. Res. Inst., ARC.

\section{Efficacy of antagonistic bio-agents against F.solani:}

The antagonistic effect of the analyzed two biocontrol agents against F.solani was tested. T.viride and F.solani were placed and cultured on PDA medium in Petri dishes for 7 days, at $28^{\circ} \mathrm{C}$. Then, a disc $(0.5$-cm-diameter) of the antagonistic fungal colony was cut and taken to the opposite colony of the pathogen. On the other hand, streak of bacterial isolates $B$. subtilis was put on PDA plates medium $2 \mathrm{~cm}$. from the plate's edge and the edge and the plates were incubated at $28 \pm 1^{\circ} \mathrm{C}$ for 24 hours, a disc $(0.5 \mathrm{~cm})$ bearing the growth of the tested fungus was placed on the PDA medium at the same distance from the edage against the bio-control agents streak. Four replicates were used in each experiment. All inoculated plates were incubated at temperature $28^{\circ} \mathrm{C}$. until the fungal growth covered the surface of any plate. The growth and reduction in mycelia of the pathogenic fungus were measured according to Fokkema, (1973).

\section{Preparation of tomato seedlings:}

Pots ( $25 \mathrm{~cm}$ diameter) were sterilized by immersing in $5 \%$ formalin solution for fifteen minute and then left for 2 days to insure complete evaporation of formalin. The sterilized pots were filled with sterilized sandy-clay soil [1:1 w/w]. Seeds of tomato cv. Peto-86 were surface sterilized with $0.2 \%$ mercuric chloride solution for two minute Then washed twice in sterilized distilled water and dried between folds of sterilized filter paper. The sterilized seeds were sown in the potteries and the plants were left to grow for 15 days. The plants were irrigated when necessary. Then, roots of tomato seedlings were treated by dipping into the suspensions of the each of the fungicide and the bio control agents each alone, for $30 \mathrm{~min}$.

\section{Preparation of antagonists' inoculum}

Inoculum of T.viride was prepared in a form of conidial suspension (10 spores $/ \mathrm{ml}$ ) as described by Sivan et al. (1984). Meanwhile. B. subtilis inoculum was prepared ( $10^{8}$ c.f.u $/ \mathrm{ml}$ ) as mentioned by Tylkowska and Szopinska (1998). Tomato seedlings were dipped, thoroughly in the bacterial suspension $\left(10^{8} \mathrm{c} . \mathrm{f} . \mathrm{u} / \mathrm{ml}\right)$ or fungal spore suspension $\left(10^{6}\right.$ conidia/ml) prepared in $0.1 \mathrm{~g}$ methyl cellulose individually. 


\section{Pot experiment:}

The pot experiment was designed under the greenhouse conditions using the plastic pots of $25 \mathrm{~cm}$ diameter, and containing $5 \mathrm{~kg}$ of disinfected loamy clay soil. Soil was infested with F.solani grown on barely grain medium at the rate of $2.5 \%$ before transplanting. Infested pots were irrigated for 5 days before transplanting. Five tomato seedlings Peto-86 $\mathrm{cv}$. were transplanted in each pot; five replicated pots were specified for each treatment in completely randomized block design. The experiment included the following treatments:

1) Non infested soil (control), 2) soil treated with F.solani only, 3) F.solani + B.subtilis, 4) F.solani + T.viride, and 5) F.solani + fungicide (Topsin-M70 250g/100L water soluble). NPK (1:1:1) mineral fertilizer was added to soil in pots and irrigated weakly. The pots were kept under greenhouse conditions until the end of the experiment. Evaluation of disease due to dead plants and survival rate of seedlings was determined after 20-45 days of transplanting, respectively, as described by Phillips and Hayman (1970). Also, dry weight of the survived plants was determined 60 days after transplanting.

\section{Field experiment}

A field experiment was carried out at Senowras, Fayoum governorate during 2017 and 2018 Growth seasons, to estimate the efficiency of test strains (T.Viride and B.subtilis) for controlling root rot disease of tomato plants. The chosen field test area was naturally infested with F.solani. The experimental design was a complete random block with three replicates. The experimental unit was $10.5 \mathrm{~m} 2$ (3.5 x $3 \mathrm{~m})$. Each unit contains twelve rows; each length was 3.5 meters each unit included twelve rows; each was $3.5 \mathrm{~m}$ in length and $25 \mathrm{~cm}$ wide. Tomato transplants were at a rate of 15 seedlings within each row. Tomato seedlings were immersed for $30 \mathrm{~min}$. in the conidial suspension $\left(10^{6} / \mathrm{ml}\right)$ of T.viride or bacterial suspension $\left(10^{8} \mathrm{c.f} . \mathrm{u} / \mathrm{ml}\right)$ of B.subtilis before transplanting individually. A fungicidal treatment was also used. Tomato seedlings were immersed directly for $30 \mathrm{~min}$. in Topsen -M70 suspension. Control plants were treated with water only. The NPK mineral fertilizers were applied as recommended by Ministry of Agriculture and Land Reclamation. The disease incidence of root rot and percentage of healthy survived plants were recorded after 45 days from transplanting.

Dehydrogenises activity was determined according to Morsy (2005). Total microbial count on modified medium, (Bunt and Rovira, 1955) was estimated by using the decimal plate count technique. Plant height, fresh and dry weights of the plant were determined. Fruit weights were also taken.

Statistical analysis: The obtained data were subjected to the proper statistically analyses using the MSTAT statistician software and the comparison was done according to Fisher (1948).L.S.D $(P<0.05)$. 


\section{RESULTS AND DISCUSSION}

\section{Efficacy of antagonistic biocontrol agents against F.solani:}

Antagonistic effect of $T$. viride and B.subtilis was evaluated against F.solani in Petri dishes containing PDA medium. Data (Fig 1) show that the two biocontrol agents succeeded to reduce the radial growth of F.solani. Trichoderme viride was more effective than B. subtilis in reducing the radial growth of F.solani, It reached 3.1 and $5.2 \mathrm{~cm}$, respectively. Moreover, T.viride inhibited the over growth of F.solani, comparing with $B$. subtilis.

Trichoderme viride and B.subtilis reduced growth percentage by 57.8 and $34.4 \%$, respectively, comparing with the control. This trend reveals essential role of both bio agents in controlling root rot disease of tomato plants. The potential of isolates used can be attributed to their ability to secrete antifungal metabolites or hydrolytic enzymes.or antifungal metabolites. These findings are in harmony with those obtained by Jorjandi et al. (2009), Morsy, et al. (2009), Bokhari, and Kahkashan (2012), and Muhanna, et al. (2016) who studied that Trichoderma spp. Produce Chitinase and B 1, 3 Glucanase. Also, Sarhan, et al. (2001), Jorjandi et al. (2009) and Mnif, et al., (2015) reported that the cell free culture filtrate of $B$. subtilis inhibited the radial growth, mycelial growth, spore germination and germ- tubes elongation of F.solani. Moreover, Kohl et al. (1991), Jorjandi et al. (2009) and Mnif et al., (2015) pointed that B. subtilis can secrete several antifungal metabolites such as bacitracin, subtilis, bicillin and bacillomycin which inhibited fungal pathogenesis.

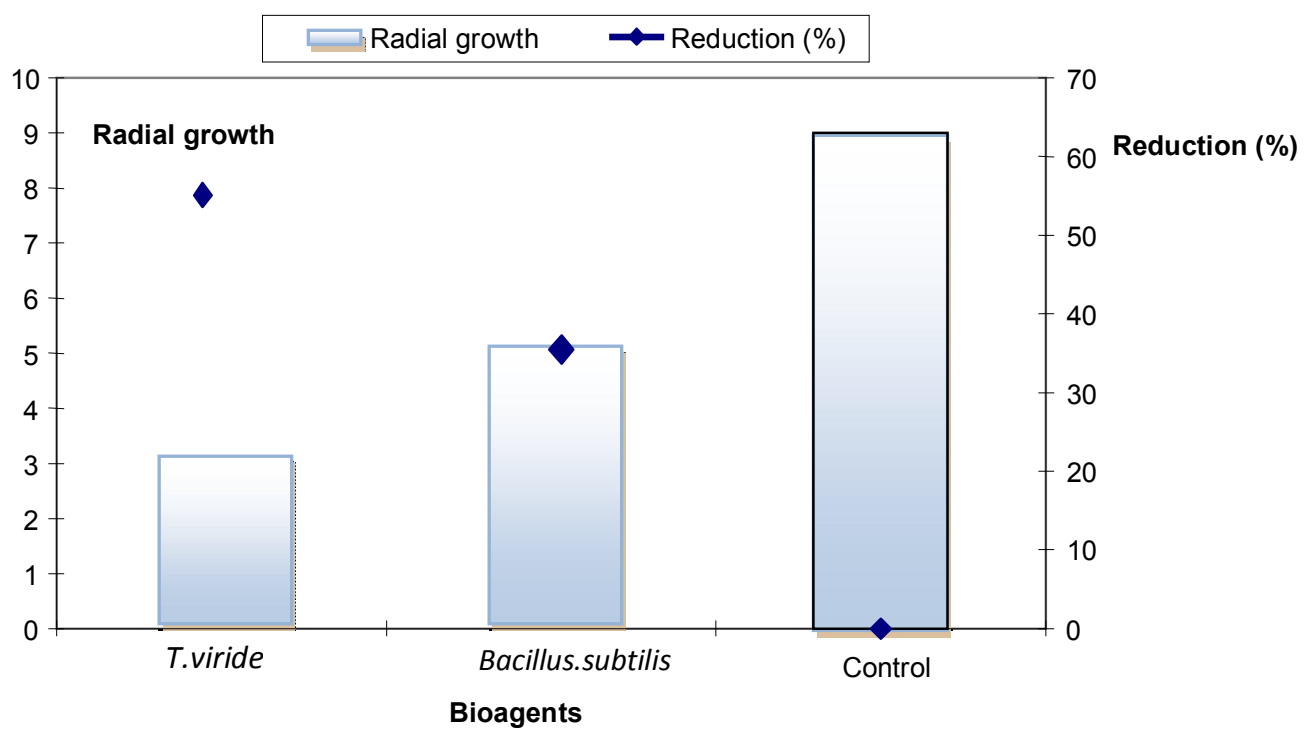

Fig. 1. Effect of T.viride and B. subtils on the radial growth of F.solani 


\section{Pot experiment:}

A pot experiment In vivo was carried out to examine the efficiency of both bio agents to antagonize F.solani under greenhouse conditions. Data presented in Table (1) reveal that soil infested with F.solani significantly increased infection of tomato seedlings and severely reduced plant survival to (36\%) compared to uninfected control $(100 \%)$ or topsin-M70 treatment (84\%).

Trichoderme viride or B.subtilis, treatment significantly increased plant survival rate compared with the infested soil, ranging between 72 and 68\%, respectively, (Table 1). Similar results were obtained by Morsy, et al. (2009), and Muhanna, et al. (2016), who cleared that T.viride and B. subtilis were effective antagonistic against F.solani. In addition, plant dry weights in the presence of T.viride, or B. subtilis were considerably higher than those in the control treatment or plants infected with F.solani. The corresponding values of plant dry weights were 2.5 , and $2.3 \mathrm{~g} / \mathrm{plant}$, respectively, are able to decrease.

Table 1. Influence of T.viride and B.subtilis against F.solani and their effect on seedling dry weight of tomato plant under greenhouse conditions.

\begin{tabular}{|l|c|c|c|}
\hline \multicolumn{1}{|c|}{ Treatments } & Dead plants, \% & $\begin{array}{c}\text { Plant Survival } \\
\text { rate } \%\end{array}$ & $\begin{array}{c}\text { Plant dry weight } \\
\text { (G/plant) }\end{array}$ \\
\hline Control & 00.0 & 100 & 1.7 \\
F.solani & 64.0 & 36.0 & 1.1 \\
F.solani+B.subtilis & 32.0 & 68.0 & 2.5 \\
F.solani+T.viride & 28.0 & 72.0 & 2.3 \\
F.solani+Topsin-M70 rate of & 16.0 & 84.0 & 3.2 \\
(250g/100 L) & 3.14 & 5.15 & 0.57 \\
\hline LSD at 0.05 & & & \\
\hline
\end{tabular}

Efficiency of T.viride and B.subtilis against F.solani under field conditions:

\section{Infection and survival percentage}

Data in Table (2) reveal that the highest infection of tomato plants with the pathogen was in untreated seedlings whereas, the lowest infection percentage was observed in seedlings treated with topsin-M70 in addition, high percentage of survival rate was recorded. 
Table 2. Influence of T.viride and B.subtilis, each alone on infection with F.solani and survival percentage of tomato plants under field conditions during 2017 and 2018 seasons.

\begin{tabular}{|l|c|c|c|c|}
\hline \multirow{2}{*}{ Treatments } & \multicolumn{2}{|c|}{2017} & \multicolumn{2}{c|}{2018} \\
\cline { 2 - 5 } & $\begin{array}{c}\text { Tomato } \\
\text { seedling } \\
\text { infection } \\
(\%)\end{array}$ & $\begin{array}{c}\text { Tomato } \\
\text { seedling } \\
\text { survival } \\
(\%)\end{array}$ & $\begin{array}{c}\text { Tomato } \\
\text { seedling } \\
\text { infection } \\
(\%)\end{array}$ & $\begin{array}{c}\text { Tomato } \\
\text { seedling } \\
\text { survival } \\
(\%)\end{array}$ \\
\hline Control & 33.3 & 66.7 & 36.1 & 63.9 \\
B. subtilis & 20.0 & 80.0 & 22.2 & 77.8 \\
T.viride & 16.6 & 83.4 & 16.6 & 83.4 \\
Topsin-M70 250g/100 L.water & 10.0 & 90.0 & 11.6 & 88.4 \\
\hline LSD at 0.05 & 4.08 & 9.1 & 6.3 & 10.25 \\
\hline
\end{tabular}

Inoculation with B.subtilis, significantly increased survival rate compared with the infested soil, being $80.0 \%$, However, higher percentage of survival rates of tomato plants was attained in response to treatment with T.viride (83.4\%). The Mechanism of action of Bacillus and Tricoderma on pathogens is by attacking pathogenic organisms and linking them by binding sugar and begins the secretion of extracellular proteases and lipase (Maude, 2006 and Bokhari, and Kahkashan, 2012).

\section{Dehydrogenase activity and microbial population:}

Dehydrogenase activity (DHA) was recorded after 45 and 60 days after transplanting (Table 3). Low DHA and total microflora values were observed with treatment of Topsin-M70 indicating the antimicrobial activity of this fungicide against the rhizospheric microflora and pathogenic fungi. Meanwhile, inoculation of tomato plants with T.viride or B. subtilis increased DHA activity and microbial flora in the tomato rhizosphere than Topsin-M70. Similar results were reported by Morsy (2005) and Zaghloul et.al. (2007) who estimated high DHA activity and total microbial flora in case of inoculation with B.subtilis or T.harzianum.

Table 3. Influence of T.viride and B.subtilis applied individually on dehydrogenase activity and total microbial counts during 20172018 seasons in soil.

\begin{tabular}{|c|c|c|c|c|c|c|c|c|}
\hline \multirow{4}{*}{ Treatments } & \multicolumn{4}{|c|}{$\begin{array}{l}\text { Dehydrogenase activity } \\
\text { ( } \mu \mathrm{g} \mathrm{TPF} / \mathrm{g} \text { dry soil/day) }\end{array}$} & \multicolumn{4}{|c|}{ Microbial total count $\left(\mathrm{cfux} 10^{6}\right)$} \\
\hline & \multicolumn{2}{|c|}{2017} & \multicolumn{2}{|c|}{2018} & \multicolumn{2}{|c|}{2017} & \multicolumn{2}{|c|}{2018} \\
\hline & \multicolumn{2}{|c|}{ (Days) } & \multicolumn{2}{|c|}{ (Days) } & \multicolumn{2}{|c|}{ (Days) } & \multicolumn{2}{|c|}{ (Days) } \\
\hline & 45 & 60 & 45 & 60 & 45 & 60 & 45 & 60 \\
\hline Control & 35.7 & 140.8 & 39.4 & 152.4 & 22.0 & 55.1 & 27.3 & 66.7 \\
\hline B. subtilis & 54.2 & 175.1 & 60.8 & 186.9 & 27.0 & 46.5 & 35.1 & 62.8 \\
\hline T.viride & 63.9 & 190.4 & 70.4 & 202.5 & 12.8 & 43.9 & 15.4 & 57.5 \\
\hline Topsin-M70 & 28.4 & 137.7 & 34.7 & 142.6 & 19.9 & 34.2 & 21.3 & 42.7 \\
\hline LSD at 0.05 & & & & & 5.39 & 7.70 & 5.43 & 6.39 \\
\hline
\end{tabular}


In general, the values of DHA activity and counts of the microbial flora of various treatments were higher at the flowering stage than the vegetative one. This finding may be due to the difference in multi-application rate of different soil microorganisms which are usually a maximum during the flowering stage. Such difference could be attributed to the qualitative and quantitative changes in the nature of root exudates during different growth stages (Abdel-Jawad, 1998).

\section{Plant Growth parameters}

Data presented in Table (4) reveal that low values of some plant growth parameters, (plant height, fresh and dry weights of plants) were found with the control treatment in comparison with other treatments. The growth parameters of tomato plants were significantly increased with the inoculation by B.subtilis and T.viride, each alone, compared with control.

Table 4. Influence of T.viride and B.subtilis applied individually on growth characters of tomato plants during 2017-2018 seasons.

\begin{tabular}{|l|c|c|c|c|c|c|}
\hline \multirow{2}{*}{\multicolumn{1}{|c|}{ Treatments }} & \multicolumn{2}{|c|}{$\begin{array}{c}\text { Plant height } \\
(\mathrm{cm})\end{array}$} & \multicolumn{2}{c|}{$\begin{array}{c}\text { Fresh weight } \\
\text { (g/plant) }\end{array}$} & \multicolumn{2}{c|}{$\begin{array}{c}\text { Dry weight } \\
\text { (g/plant) }\end{array}$} \\
\cline { 2 - 7 } & 2017 & 2018 & 2017 & 2018 & 2017 & 2018 \\
\hline Control & 50.8 & 54.5 & 95.2 & 138.7 & 13.9 & 17.2 \\
B.subtilis & 65.0 & 70.6 & 205.9 & 337.4 & 35.8 & 44.9 \\
T.viride & 62.7 & 65.1 & 167.5 & 297.2 & 26.1 & 35.5 \\
Topsin-M70 & 73.2 & 70.9 & 356.7 & 420.9 & 58.2 & 64.9 \\
\hline LSD at 0.05 & 12.6 & 11.3 & 9.2 & 13.9 & 7.3 & 4.3 \\
\hline
\end{tabular}

The promotion of tomato growth parameters using B.subtilis and T.viride isolates may be due to their abilities to produce phytohormones, vitamins and solublizing minerals besides, their role in inhibiting Fusarium growth (Morsy, 2005 ,Zaghloul et al.2007 Morsy, et al.2009, and Muhanna, et al.2016). This increase in growth was as a result of disease control and increased hormone production.

\section{Fruits weight}

Data in Table (5) show a decrease in the fruit weight of tomato plants of control treatment. However, the significant increase was determined by fungicidal treatment (Table 5).

Table 5. Influence of T.viride and B.subtilis applied individually on fruit yield of tomato plants during 2017-2018 seasons.

\begin{tabular}{|l|c|c|}
\hline \multirow{2}{*}{ Treatments } & \multicolumn{2}{|c|}{$\begin{array}{c}\text { Fruits yield } \\
\text { (kg/plant) }\end{array}$} \\
\cline { 2 - 3 } & 2017 & 2018 \\
\hline Control & 0.12 & 0.15 \\
B.subtilis & 0.15 & 0.17 \\
T.viride & 0.17 & 0.19 \\
Topsin-M70) & 0.20 & 0.22 \\
\hline LSD at 0.05 & 0.31 & 0.25 \\
\hline
\end{tabular}


The treated tomato with T.viride only gave higher records of fruit weight than those treated with B.subtilis. However, this increment was not significant. Moreover, Topsin-M70 gained significant increase in fruits weight of tomato plants compared to the bio agents.

This result could be referred to the synergistic effect between the microbial populations of the rhizosphere and biocontrol agents. In this respect, Kohl et al.(1991), Jorjandi et al.2009) and Muhanna, et al.(2016) reported that application of selected antagonists ( $B$. subilis, $T$. viride) individually significantly increased weight of fruits and the total yield of tomato fruits.

\section{REFERENCES}

1. Abdel-Jawad, A. 1998. Effect of some soil microorganisms on the fertility of Egyptian desert soil. M.Sc. Thesis, Fac. of Sci., Ain Shams University.

2. Abdel-Kader, M. M.; El-Mougy, Nehal. S.; Aly, M. D. E.; Lashin. 2012. Different approaches of bio-control agents for controlling root rot incidence of some vegetables under greenhouse conditions. International Journal of Agriculture and Forestry; 2(1):115-127.

3. Abdel-Kader, M. M.; El-Mougy, Nehal. S.; Aly, M. D. E.; Lashin, S. M.; ElMohamady, R. S. 2012. Soil drench with fungicides alternatives against root rot incidence of some vegetables under greenhouse conditions. International Journal of Agriculture and Forestry; 2(2):61-69.

4. Bokhari, N. A.and Kahkashan Perveen. 2012. Antagonistic action of Trichoderma harzianum and Trichoderma viride against Fusarium solani causing root rot of tomato. African Journal of Microbiology Research; 6(44):7193-7197.

5. Bunt, M.E. and Rovira, A.O. 1955. Microbiological studies of some sub-Antarctic soil. J. Soil Sci., 6: 119-128.

6. Fisher, R.A. 1948. Statistical Method for Research Works.Oliver and boya, Australia. :354 p.

7. Fokkema,, N.J. 1973. The role of saprophytic fungi in antagonism against Derchslera sorokaniana (Helminthosporium sativum) on agar plates and on rye leaves with pollen. Physiol. Plant Pathol., 3: 195-205.

8. Giovannucci, E. 1999. Tomatoe based products, Lycopene and canser:Review of the epidemiologic literature .J.Nat.Cancer Inst., 91: 317-331.

9. Jorjandi, M., Bonjar, G.H.S., Baghizadeh, A., Sirchi, G.R.S, Massumi, H., Baniasadi, F., Aghighi, S. and Farokhi, P.R. 2009. Biocontrol of Botrytis allii Munn the causal agent of neck rot, the post harvest disease in onion, by use of a new iranian isolate of streptomyces. American Journal of Agricultural and Biological Sciences, 4 (1). pp. 72-78.

10. Kohl,J.;Molhoek,W.L.; and Fokkema,N.J. 1991. Biological control of tomato root rot Botrytis aclada protection of wounds made by leaf topping. Biological Control 
Science and Technology. 1(4):261-269.

11. Maude,R.B. 2006. Tomato disease. The Epidemiology of Plant Diseases Edited by B.M. COOKE and B. KAYE Second Edition. University College Dublin, Ireland: 491520.

12. Mnif, I.; Hammami, I.; Triki, M. A.; Azabou, M. C.; Ellouze-Chaabouni, S. and Ghribi,D. 2015. Antifungal efficiency of a lipopeptide biosurfactant derived from Bacillus subtilis SPB1 versus the phytopathogenic fungus, Fusarium solani. Environmental Science and Pollution Research; 22(22):18137-18147.

13. Morsy, Ebtsam M., 2005. Role of growth promoting substances producing microorganisms on tomato plant and control of some root rot fungi. Ph.D. Thesis, Fac. of Agric. Ain Shams Univ., Cairo.

14. Morsy, E. M.; Abdel-Kawi, K. A. and Khalil, M. N. A. 2009. Efficiency of Trichoderma viride and Bacillus subtilis as biocontrol agents gainst Fusarium solani on tomato plants. Egyptian Journal of Phytopathology; 37(1):47-57.

15. Muhanna, Naglaa A. S.; Essa, T. A.; Manal, A. H. E.; Kamel, S. M. 2016. Efficacy of free and formulated arbuscular mycorrhiza, Trichoderma viride and Pseudomonas fluorescens on controlling tomato root rot diseases. Egyptian Journal of Biological Pest Control; 26(3):477-486.

16. Phillips, J.A. and Hayman, D.S. 1970. Improved producer for clearing roots and staining parasitic vascular arbuscular mycorrhizal fungi for rapid assessment of infection. Trans. Br. Mycol. Soc., 55: 158-166.

17. Sarhan, M.M; Ezzat, S.M.; Tohamy, A.A.; El-Essawy, A.A. and Mohamed, F.A. 2001. Biocontrol of Fusarium tomato wilt diseases by Bacillus subtilis. Egypt. J Microbiol., 36: 376-386.

18. Sivan, B.; Elad, Y. and Chet, I. 1984. Biological control effects of a new isolate of Trichoderma harzianum on Pythium aphanidermatum. Phytopathology, 74: 498503.

19. Soytong, K. Srinon, W.; Ratanacherdchai, K.; Kanokmedhakul, S. and Kanokmedhakul, K. 2005. Application of antagonistic fungi to control anthracnose disease of grape. J. Agricultural Technology 1: 33-42.

20. Tylkowska,K. and Szopinska,D. 1998. Effects of fungicides and Penicillium spp. on health and germination of tomato seed.Roczniki Akademii Rolniczej w Poznaniu, grodnictwo. 27: 339-344.

21. Weller, D. Raaijmakers, J.; Mcspadden Gardener, B.B. and Thomashow, L.S. 2002. Microbial population responsible for specific soil suppressiveness to plant pathogens. Annual Review of Phytopathology, 40: 39-48.

22. Zaghloul, R.A.; Hanafy, Ehsan, A.; Neweigy, N. A. and Khalifa, Neamat, A. 2007. Application of biofertilization and biological control for tomato production. 12th Conference of Microbiology; Cairo, Egypt, 18(22): pp. 198-212. 


\section{كفاءة التريكودرما فيردي و الباسيلس ساتلس في المكافحة الحيوية

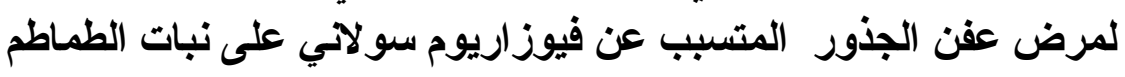

\section{محمد عفت خليل إبر اهيم خليل}

قسم بحوث المكافحة الهنكاملة_ معهُ بحوث أمر اض النباتات ـ مركز البحوث الزر اعيةـ الجيزةــ مصر

تعتبر الطماطم (صنف بيتو -86) أحد أهم محاصيل الحقل التي تصاب بالعديد من الأمر اض الهامة

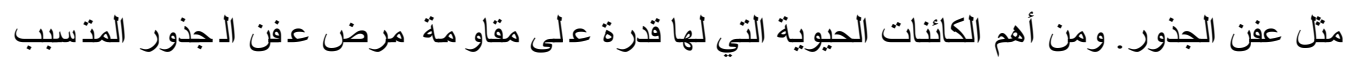

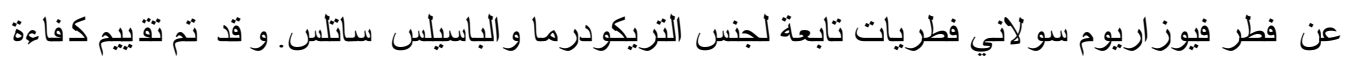

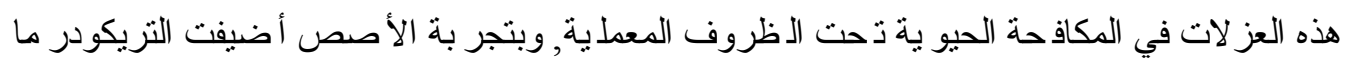

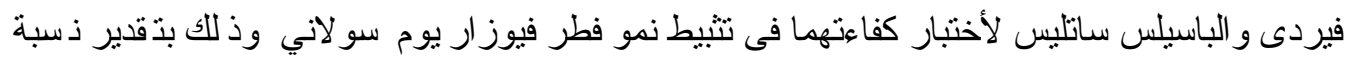

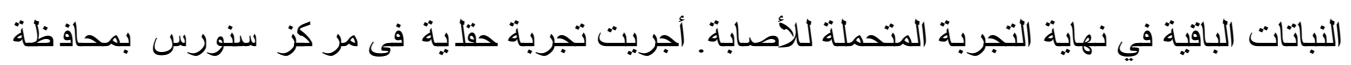

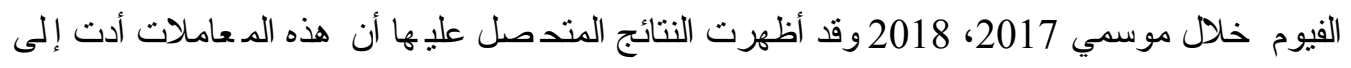

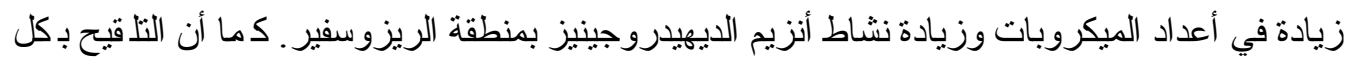

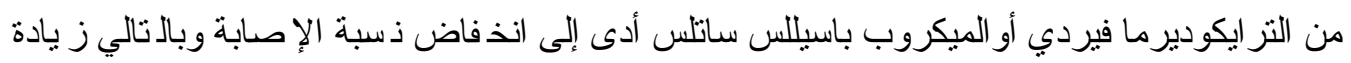

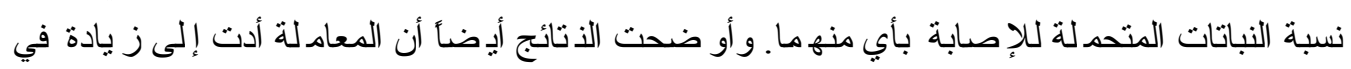

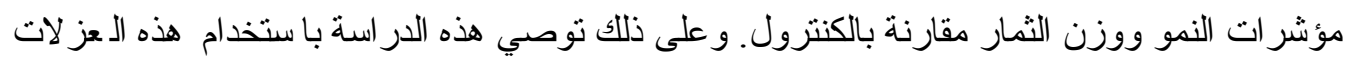

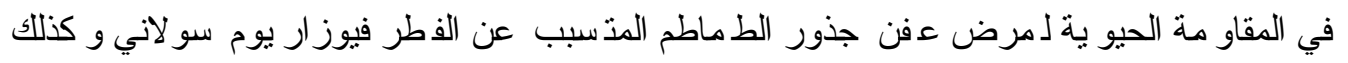

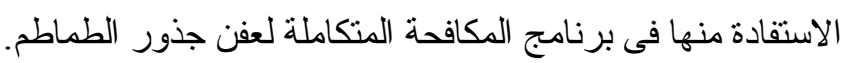

